\author{
Sabina KORDANA ${ }^{1}$ \\ Daniel SŁYŚ
}

\title{
WSPOMAGANIE DECYZJI O WYBORZE OPTYMALNEGO ROZWIĄZANIA SYSTEMU PRZYGOTOWANIA CIEPŁEJ WODY
}

\begin{abstract}
W Polsce obserwuje się obecnie tendencję do obniżania energochłonności obiektów budowlanych. Główne działania skupione są jednak na możliwościach zredukowania zapotrzebowania na energię wykorzystywaną na potrzeby ogrzewania pomieszczeń, podczas gdy potencjał tkwiący w alternatywnych rozwiązaniach systemów przygotowania ciepłej wody użytkowej nie znajduje tak szerokiego zainteresowania. Tymczasem podgrzewanie wody stanowi drugą co do wielkości pozycję w bilansie zużycia energii w sektorze budownictwa, co skłania do oszczędzania energii przeznaczonej także na ten cel. Problemem pozostaje jednak konieczność poniesienia wysokich nakładów inwestycyjnych na realizację instalacji energooszczędnych, która może budzić opór ze strony mieszkańców. W odpowiedzi na powyższą kwestię zdefiniowano pozostałe kryteria decydujące o racjonalności zastosowania odmiennych rozwiązań systemu przygotowania ciepłej wody oraz przeprowadzono analizę dla przykładowego obiektu. Jako narzędzie oceny rozpatrywanych wariantów modernizacji istniejącego systemu wykorzystano jedną z najczęściej stosowanych wieloatrybutowych metod oceny projektów inwestycyjnych, to jest metodę scoringową. Przeprowadzone badania wykazały, iż uwzględnienie w analizie wielu kryteriów, takich jak kryteria: ekonomiczne, eksploatacyjne, społeczne, środowiskowe i techniczne, pozwala wskazać wiele korzyści związanych z wykorzystaniem niekonwencjonalnych źródeł energii w celu podgrzewania wody w wewnętrznych instalacjach wodociągowych. Uzyskana łączna ocena badanych wariantów projektowych potwierdziła także, że znaczenie korzyści płynących z zastąpienia paliw kopalnych źródłami odnawialnymi i odpadowymi jest tak duże, że pozwala przezwyciężyć niedogodności związane z wysoką ceną zakupu i montażu stosownych urządzeń.
\end{abstract}

Słowa kluczowe: kryteria decyzyjne, odzysk ciepła odpadowego ze ścieków, metody wieloatrybutowe, wykorzystanie energii słonecznej

\footnotetext{
${ }^{1}$ Autor do korespondencji / corresponding author: Sabina Kordana, Politechnika Rzeszowska, Wydział Budownictwa, Inżynierii Środowiska i Architektury, Zakład Infrastruktury i Ekorozwoju, al. Powstańców Warszawy 6, 35-959 Rzeszów, tel. +48 17 8651071, e-mail: sk@ prz.edu.pl

2 Daniel Słyś, Politechnika Rzeszowska, Wydział Budownictwa, Inżynierii Środowiska i Architektury, Zakład Infrastruktury i Ekorozwoju, al. Powstańców Warszawy 6, 35-959 Rzeszów, tel. +48 17 8651784, e-mail: daniels@ @prz.edu.pl
} 


\section{Wprowadzenie}

W ostatnich latach daje się zaobserwować wyraźne zmiany zachodzące w sektorach budownictwa mieszkaniowego i usługowego. Zmiany te ukierunkowane są głównie na ograniczenie zużycia energii wykorzystywanej w poszczególnych obiektach oraz minimalizowanie negatywnego wpływu stosowanych w nich rozwiązań i technologii na środowisko. Takie podejście do kwestii zarządzania budynkami jest niewątpliwie podejściem zrównoważonym i należy dążyć do jego utrzymania w dłuższej perspektywie czasu. Istotne jest jednak, aby obniżeniu energochłonności obiektów budowlanych nie towarzyszyło pogorszenie komfortu życia i pracy ich użytkowników. Możliwość zaspokojenia potrzeb społecznych powinna bowiem pozostać główną determinantą wyboru rozwiązań stosowanych zarówno $\mathrm{w}$ budownictwie, jak i w innych gałęziach gospodarki, przykładowo zarządzaniu wodami opadowymi $[21,26]$ czy ochronie przeciwpowodziowej [34].

Wielkość zapotrzebowania na energię wykorzystywaną w poszczególnych obiektach budowlanych uzależniona jest od szeregu czynników związanych z ich charakterystyką i przeznaczeniem. Do najważniejszych z nich zaliczyć należy [11,33]: lokalizację budynku oraz jego konstrukcję i kubaturę, wyposażenie pomieszczeń, liczbę użytkowników i ich preferencje, jak również efektywność eksploatowanych urządzeń. W obiektach mieszkalnych duże znaczenie posiada dodatkowo cena energii oraz dostępny budżet domowy. W każdym przypadku, bez względu na pełnioną przez budynek funkcję, istnieje jednak możliwość zredukowania popytu na energię wykorzystywaną na potrzeby oświetlenia [23], zasilania urządzeń elektrycznych [13], wentylacji i klimatyzacji [19], przygotowania ciepłej wody użytkowej [15] czy ogrzewania pomieszczeń [5].

W Polsce największa uwaga poświęcana jest ostatniemu z wymienionych kierunków użytkowania energii, to jest ogrzewaniu pomieszczeń, ze względu na jego znaczący udział $\mathrm{w}$ całkowitym bilansie zużycia energii $\mathrm{w}$ budynkach. W przypadku gospodarstw domowych udział energii wykorzystywanej na ten cel obniżył się pomiędzy rokiem 1993 a 2012 o kilka punktów procentowych, podczas gdy znaczenie przygotowania ciepłej wody użytkowej nie uległo w tym okresie istotnym zmianom [14]. Podobna tendencja obserwowana jest także w obiektach o innym przeznaczeniu, co wskazuje na potrzebę implementacji rozwiązań, których założeniem jest zredukowanie zużycia paliw na potrzeby podgrzewania wody w instalacjach wewnętrznych budynków.

Znaczna część wykorzystywanych na świecie technologii zakłada obniżenie zapotrzebowania na energię poprzez podnoszenie efektywności źródła ciepła [30] oraz stosowanie odpowiedniej armatury czerpalnej [28]. Pozostałe rozwiązania opierają się natomiast na możliwości zastąpienia paliw kopalnych niekonwencjonalnymi źródłami energii, do których zaliczane są źródła odnawialne oraz odpadowe. W przypadku energii odnawialnej największe znaczenie posiada 
energia słoneczna $[9,17]$. O racjonalności jej wykorzystania w wewnętrznych instalacjach wodociągowych decyduje jednak wiele parametrów, takich jak lokalizacja instalacji solarnej czy występujące w ciągu roku zmiany natężenia promieniowania słonecznego. Głównym nośnikiem energii odpadowej, która może zostać wykorzystana do wstępnego podgrzewania wody, są z kolei ciepłe ścieki $[32,35]$. Niesioną przez to medium energię cieplną można odzyskać dzięki zastosowaniu specjalnie do tego celu przeznaczonych wymienników ciepła Drain Water Heat Recovery (DWHR) [25], pomp ciepła [8] bądź obu wymienionych urządzeń $[7,31]$. Warto również podkreślić, iż system odzysku ciepła ze ścieków odprowadzanych z poszczególnych urządzeń sanitarnych może zostać połączony z instalacją wykorzystania ścieków szarych [27], co stwarza możliwość równoczesnego oszczędzania obu głównych zasobów środowiska, to jest surowców energetycznych oraz wody.

Bogaty wachlarz dostępnych rozwiązań systemów umożliwiających ograniczenie zużycia energii wykorzystywanej na potrzeby przygotowania ciepłej wody użytkowej w budynkach zachęca do ich szerokiej aplikacji. W warunkach polskich problemem pozostaje jednak kwestia wysokich nakładów inwestycyjnych, które należy ponieść na zakup i montaż poszczególnych instalacji, co zniechęca ich potencjalnych użytkowników. Istnieje zatem potrzeba zdefiniowania oraz zbadania pozostałych kryteriów decyzyjnych dotyczących wyboru sposobu podgrzewania wody w budynkach. W tym celu wyznaczono czynniki determinujące zasadność zastosowania przedstawionych systemów w wewnętrznych instalacjach wodociągowych oraz przeprowadzono analizę dla przykładowego obiektu.

\section{Opis analizowanego przypadku}

\subsection{Charakterystyka budynku}

Badania zasadności zastosowania różnych rozwiązań systemu przygotowania ciepłej wody użytkowej przeprowadzono dla jednorodzinnego budynku mieszkalnego o powierzchni $180 \mathrm{~m}^{2}$. Budynek ten zlokalizowany jest na terenie województwa podkarpackiego i aktualnie zamieszkuje go 5 osób. W analizowanym obiekcie znajdują się cztery urządzenia, w których wykorzystywana jest woda zmieszana, to jest prysznic, zlewozmywak oraz dwie umywalki. Wszystkie te urządzenia wyposażone są $\mathrm{w}$ termostatyczne zawory mieszające.

Zużycie ciepłej wody użytkowej o temperaturze $T_{w c}=55^{\circ} \mathrm{C}$ określono dla rozpatrywanego budynku na podstawie pracy [10] i wynosi ono $252 \mathrm{dm}^{3} / \mathrm{d}$. Woda ta przygotowywana jest za pomocą kotła gazowego, który zintegrowany jest z pojemnościowym podgrzewaczem ciepłej wody. Ciepło spalania wykorzystywanego $\mathrm{w}$ instalacji gazu przyjęto jako średnią arytmetyczną $\mathrm{z}$ wartości przypisanych dla obszaru Gminy Miasta Rzeszów dla roku 2015 [20] i jest ono równe $H=39,941 \mathrm{MJ} / \mathrm{m}^{3}$. Sprawności wytwarzania ciepła oraz średniej rocznej jego 
akumulacji założono na poziomie $\eta_{w c}=\eta_{a}=0,85$, natomiast sprawność przesyłu ciepłej wody $-\eta_{p}=0,8[10]$.

Zastosowane rozwiązanie instalacji wewnętrznych w budynku pozwala zapewnić komfort użytkowania ciepłej wody. Eksploatacja takiego systemu skutkuje jednak zużyciem gazu na potrzeby podgrzewania wody w ilości kilkuset metrów sześciennych rocznie oraz emisją do atmosfery znacznej ilości zanieczyszczeń, takich jak dwutlenek węgla czy tlenki azotu. W celu określenia możliwości zredukowania zużycia gazu ziemnego wykorzystywanego na potrzeby podgrzewania wody w rozpatrywanym budynku oraz związanego z tym niekorzystnego wpływu spalania paliw na środowisko, przeanalizowano następujące warianty modernizacji istniejącego systemu przygotowania ciepłej wody użytkowej (wariant 0):

- wariant 1 - montaż na odpływie ścieków szarych z prysznica wymiennika ciepła DWHR, w którym podgrzewana będzie woda doprowadzana do zaworu mieszającego prysznica w miejsce wody zimnej (rys. 1),

- wariant 2 - montaż kolektorów słonecznych, za pomocą których podgrzewana będzie woda magazynowana w zbiorniku; woda ze zbiornika kierowana będzie następnie do istniejącego urządzenia podgrzewającego wodę bądź bezpośrednio do zaworu mieszającego prysznica (rys. 2).

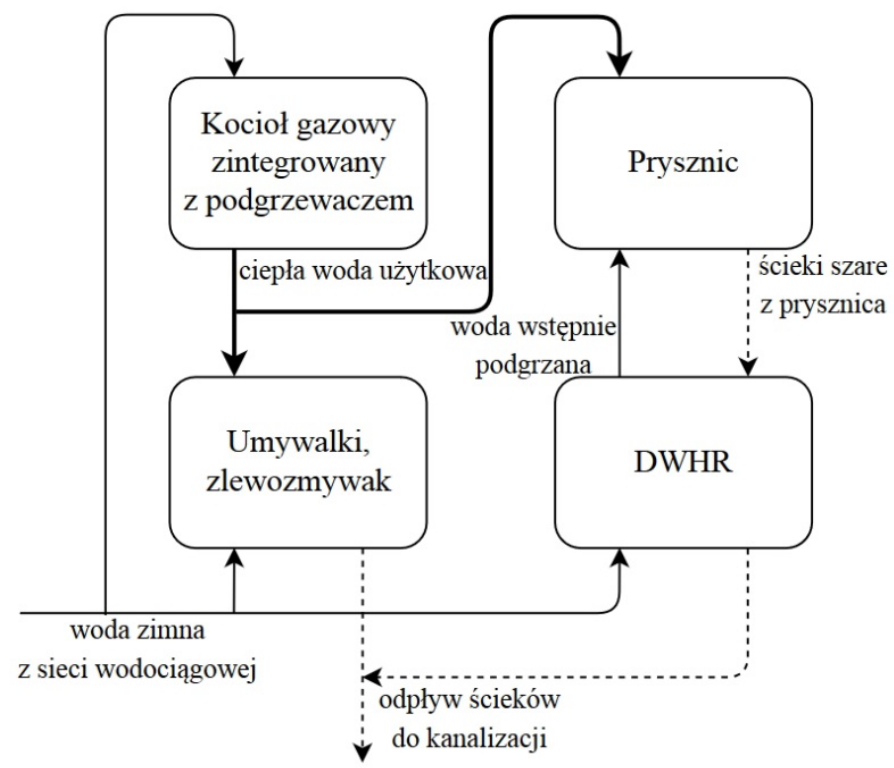

Rys. 1. Schemat blokowy systemu w wariancie 1

Fig. 1. Schematic diagram of the system in variant 1 




Rys. 2. Schemat blokowy systemu w wariancie 2

Fig. 2. Schematic diagram of the system in variant 2

\subsection{Opis instalacji w wariancie 1}

W rozpatrywanym wariancie 1 alternatywne źródło energii wykorzystywanej na potrzeby podgrzewania wody stanowić będzie energia odpadowa niesiona przez ścieki szare odprowadzane z prysznica. Zawarte w ściekach ciepło odzyskiwane będzie za pomocą zainstalowanego w odwodnieniu liniowym prysznica wymiennika ciepła DWHR i przekazywane do przepływającej przez to urządzenie wody. Wstępnie podgrzana woda, ze względu na lokalizację wymiennika ciepła, doprowadzona zostanie tylko do zaworu mieszającego prysznica w miejsce wody zimnej, natomiast zintegrowany z kotłem zasobnikowy podgrzewacz wody zasilany będzie wodą wodociągową, tak jak ma to miejsce obecnie. Zastosowanie takiego rozwiązania pozwoli ograniczyć ilość ciepłej wody użytkowej, którą należy doprowadzić do baterii czerpalnej prysznica w celu otrzymania preferowanej temperatury wody zmieszanej, a dzięki temu także zużycie gazu wykorzystywanego w celu podgrzewania wody.

W badaniach wykorzystano model obliczeniowy opracowany przez autorów [25]. Ilość możliwej do odzyskania ze ścieków energii określono na podstawie udostępnionej przez producenta analizowanego urządzenia dokumentacji technicznej, natomiast parametry wody odczytano z tablic jej właściwości fizycznych. Pozostałe dane przyjęte do obliczeń są następujące:

- temperatura ciepłej wody użytkowej $T_{w c}=55^{\circ} \mathrm{C}$, 
- temperatura wody zimnej $T_{w z}=10^{\circ} \mathrm{C}$,

- temperatura wody zmieszanej $T_{w m}=40^{\circ} \mathrm{C}$,

- wypływ wody zmieszanej z baterii czerpalnej prysznica $q_{w m}=7 \mathrm{dm}^{3} / \mathrm{min}$.

Znając całkowite zapotrzebowanie na ciepłą wodę użytkową w rozpatrywanym budynku oraz procentową strukturę zużycia wody w gospodarstwach domowych [6], zużycie wody zmieszanej wykorzystywanej na potrzeby kąpieli pod prysznicem przyjęto równe $q_{p}=38,5 \mathrm{dm}^{3} /(\mathrm{M} \cdot \mathrm{d})$.

\subsection{Opis instalacji w wariancie 2}

Analizowany wariant 2 modernizacji instalacji wewnętrznych w budynku zakłada wykorzystanie energii promieniowania słonecznego w celu wstępnego podgrzewania wody magazynowanej w solarnym zbiorniku jednowężownicowym o pojemności $400 \mathrm{dm}^{3}$, z którego będzie ona kierowana do podgrzewacza bądź bezpośrednio do punktów czerpalnych. Działanie układu sterowane będzie przez zawór trójdrogowy z termostatem. W związku z tym, iż niektóre źródła literaturowe, np. [2], zwracają obecnie uwagę na możliwość obniżenia wymaganej temperatury ciepłej wody użytkowej w przypadku zastosowania niekonwencjonalnych rozwiązań instalacji, w wariancie tym przyjęto, iż wystarczająca temperatura wody ciepłej doprowadzanej do zaworów mieszających poszczególnych punktów czerpalnych to $T_{w c}{ }^{\prime}=T_{w m}=40^{\circ} \mathrm{C}$. W przypadku, gdy temperatura wody w zbiorniku przekroczy tę wartość, kierowana będzie bezpośrednio do zaworu mieszającego. $\mathrm{W}$ przeciwnym razie wymagane będzie jej dodatkowe podgrzanie do temperatury $T_{w c}=55^{\circ} \mathrm{C}$ w eksploatowanym obecnie urządzeniu, które dzięki podgrzewaniu całej objętości zgromadzonej w nim wody nie posiada wymagań co do minimalnego przepływu. Dodatkowo układ posiadał będzie także awaryjne zasilanie istniejącego źródła ciepła wodą zimną, które pominięto na schemacie.

Analizę wykonano przy wykorzystaniu danych dotyczących średnich wartości natężenia promieniowania słonecznego dla Rzeszowa i kolektorów o ekspozycji południowej oraz nachyleniu $45^{\circ}$ [29]. W badaniach założono, że energia promieniowania słonecznego absorbowana będzie przez 3 kolektory słoneczne o łącznej powierzchni czynnej równej $A=6,12 \mathrm{~m}^{2}$. Sprawność optyczna rozpatrywanych urządzeń jest równa $\eta_{4}=0,8$. Wartości sprawności przesyłu i akumulacji ciepła przyjęto analogicznie jak w wariancie 0 .

\section{Identyfikacja kryteriów warunkujących wybór najkorzystniejszego sposobu podgrzewania wody}

Decyzja o wyborze konkretnego wariantu inwestycyjnego podejmowana jest często w oparciu o tylko jedno kryterium. W wielu przypadkach podjęcie racjonalnej decyzji inwestycyjnej uzależnione jest jednak od szeregu wzajemnie się wykluczających czynników, co wymusza na decydencie zastosowanie zaa- 
wansowanych technik wspomagania decyzji. Do technik tych zaliczane są m.in. metody wieloatrybutowe. Ich założeniem jest obiektywne przeanalizowanie rozpatrywanych opcji decyzyjnych pod kątem przyjętych kryteriów oraz wybór tej, której implementacja w danych warunkach będzie najkorzystniejsza [1, 12].

Aplikacja metod wielokryterialnych w celu analizy odmiennych wariantów inwestycyjnych systemu przygotowania ciepłej wody użytkowej należy do rzadkości. Warto również podkreślić, iż prowadzone dotychczas badania zakładały zazwyczaj całościową ocenę systemu zaopatrzenia budynku w energię, w którym dominującą rolę odgrywa ogrzewanie pomieszczeń [4]. Konsekwencją takiego podejścia jest brak uwzględnienia na etapie analizy niektórych technologii, których zastosowanie pozwala w istotny sposób ograniczyć zapotrzebowanie na energię wykorzystywaną na potrzeby przygotowania ciepłej wody. Z tego względu techniki bazujące na odzysku ciepła odpadowego ze ścieków szarych nie są w ogóle brane pod uwagę jako potencjalne opcje decyzyjne. Tymczasem badania opisane w pracach $[15,24]$ wykazały, że wykorzystanie wymienników ciepła DWHR pozwala znacząco ograniczyć zużycie energii, a dzięki temu także osiągnąć wyraźne oszczędności finansowe.

Opłacalność inwestycji, wyrażona wysokością kosztów cyklu życia $L C C$ bądź wartością zaktualizowaną netto $N P V$, jest jednak tylko jednym z czynników decydujących o zasadności zastosowania konkretnych rozwiązań. W tabeli 1 zestawiono kryteria warunkujące wybór optymalnego rozwiązania systemu przygotowania ciepłej wody użytkowej. W badaniach, oprócz wspomnianego kryterium ekonomicznego, uwzględniono także czynniki eksploatacyjne, społeczne, środowiskowe oraz techniczne.

\section{Metodyka oceny systemów przygotowania ciepłej wody użytkowej}

Jako narzędzie oceny systemów umożliwiających ograniczenie zużycia energii na potrzeby podgrzewania wody w budynku wykorzystano jedną z najczęściej stosowanych wielokryterialnych metod oceny projektów inwestycyjnych, to jest metodę scoringową. W metodzie scoringowej ocena analizowanych opcji decyzyjnych dokonywana jest na podstawie punktacji, która została im przydzielona w świetle rozpatrywanych kryteriów [18]. Jedna ze stosowanych wersji tej metody zakłada, że wykorzystywana skala ocen jest stała, natomiast poszczególnym kryteriom przyporządkowywane są wagi, których suma jest równa 1,0 . O pozycji danego wariantu inwestycyjnego w rankingu końcowym decyduje w takiej sytuacji suma iloczynów przypisanych wag oraz liczby przyznanych punktów [18]. 
Tabela 1. Kryteria decyzyjne warunkujące wybór optymalnego rozwiązania systemu przygotowania ciepłej wody użytkowej

Table 1. Decision criteria for selecting the most favorable type of hot water system

\begin{tabular}{|c|c|}
\hline Kryteria decyzyjne & Podkryteria decyzyjne \\
\hline \multirow{2}{*}{$K_{1}:$ Ekonomiczne } & $K_{11}:$ Rentowność inwestycji \\
\hline & $K_{12}:$ Możliwość uzyskania dofinansowania \\
\hline \multirow{5}{*}{$K_{2}:$ Eksploatacyjne } & $K_{21}:$ Bezpieczeństwo eksploatacji \\
\hline & $K_{22}$ : Długi okres użytkowania instalacji \\
\hline & $K_{23}$ : Ograniczone ryzyko awarii \\
\hline & $\begin{array}{c}K_{24}: \text { Ograniczone ryzyko spadku wydajności } \\
\text { instalacji }\end{array}$ \\
\hline & $K_{25}$ : Rzadkie zabiegi konserwacyjne \\
\hline \multirow[t]{2}{*}{$K_{3}:$ Społeczne } & $\begin{array}{c}K_{31}: \text { Zapewnienie komfortu użytkowania } \\
\text { instalacji }\end{array}$ \\
\hline & $K_{32}$ : Wpływ na rozwój świadomości ekologicznej \\
\hline \multirow{5}{*}{$K_{4}:$ Środowiskowe } & $K_{41}:$ Niewielkie zużycie paliw kopalnych \\
\hline & $K_{42}:$ Niska emisja $\mathrm{CO}_{2}$ \\
\hline & $K_{43}:$ Niska emisja $\mathrm{NO}_{\mathrm{x}} / \mathrm{NO}_{2}$ \\
\hline & $K_{44}:$ Niska emisja $\mathrm{SO}_{x} / \mathrm{SO}_{2}$ \\
\hline & $K_{45}$ : Niska emisja pozostałych zanieczyszczeń \\
\hline \multirow{5}{*}{$K_{5}:$ Techniczne } & $K_{51}:$ Łatwość wykonania instalacji \\
\hline & $\begin{array}{c}K_{52}: \text { Możliwość połączenia systemu z instalacją } \\
\text { centralnego ogrzewania }\end{array}$ \\
\hline & $\begin{array}{c}K_{53}: \text { Możliwość łącznego wykorzystania różnych } \\
\text { źródeł energii }\end{array}$ \\
\hline & $\begin{array}{l}K_{54}: \text { Niezależność dostępności źródła energii } \\
\text { od czynników zewnętrznych }\end{array}$ \\
\hline & $K_{55}:$ Wysoka efektywność instalacji \\
\hline
\end{tabular}

Rentowność inwestycji oceniono przy wykorzystaniu metody wartości zaktualizowanej netto [3]. O opłacalności przedsięwzięcia decyduje w tym przypadku wysokość wskaźnika $N P V$, którą można określić w oparciu o wzór (1).

$$
N P V_{k}=\sum_{t=0}^{n}\left(\frac{C F_{k t}}{(1+r)^{t}}\right)
$$


gdzie: $N P V_{k}$ - wartość zaktualizowana netto wariantu $k$ inwestycji;

$C F_{k t}$ - przepływy pieniężne w wariancie $k \mathrm{w}$ roku $t$;

$t$ - rok eksploatacji systemu;

$n$ - liczba lat eksploatacji systemu;

$r$ - stopa dyskontowa.

W sytuacji, gdy NPV osiąga wartość dodatnią, analizowany projekt inwestycyjny należy uznać za korzystny pod względem finansowym, a prognozowane zyski są tym większe, im wyższa jest otrzymana wartość wskaźnika.

W obu rozpatrywanych opcjach modernizacji istniejącego systemu przygotowania ciepłej wody użytkowej uwzględniono wysokość nakładów inwestycyjnych koniecznych do poniesienia na zakup i montaż urządzeń w roku 0 analizy. W wariancie 2 pod uwagę wzięto także dodatkowe koszty związane z koniecznością wymiany płynu solarnego w odstępach co 5 lat oraz wykonywania regularnych przeglądów technicznych instalacji w całym okresie jej eksploatacji, jak również koszty użytkowania pompy obiegowej i sterownika instalacji. Z kolei do zysków zakwalifikowano w obydwu przypadkach potencjalne oszczędności finansowe wynikające ze zredukowania zużycia gazu ziemnego.

W obliczeniach wysokości wskaźnika $N P V$ przyjęto następujące dane:

- wysokość nakładów inwestycyjnych na zakup i montaż systemu w wariancie 1: $I N V_{1}=4000 \mathrm{zł}$,

- wysokość nakładów inwestycyjnych na zakup i montaż systemu w wariancie $2: I N V_{2}=14000 \mathrm{zl}$,

- koszt wymiany płynu solarnego: $K_{w p}=300 \mathrm{zł}$,

- koszt działania pompy obiegowej i sterownika instalacji solarnej oraz okresowych przeglądów instalacji: $K_{p o}=200 \mathrm{zz} / \mathrm{rok}$,

- cena gazu ziemnego w roku 0 analizy: $C_{e 0}=0,17 \mathrm{zł} / \mathrm{kWh}$,

- założony coroczny wzrost cen nośnika energii: $i_{g}=2 \%$,

- stopa dyskontowa: $r=5 \%$,

- okres użytkowania systemu: $n=15$ lat.

Wpływ eksploatacji systemu na środowisko przeanalizowano na podstawie wielkości emisji produktów spalania paliw do atmosfery. Wskaźniki emisji poszczególnych związków przyjęto w oparciu o wytyczne Krajowego Ośrodka Bilansowania i Zarządzania Emisjami KOBiZE [16].

Znaczenie pozostałych kryteriów warunkujących wybór optymalnego rozwiązania systemu podgrzewania wody określono na podstawie opinii ekspertów.

\section{Analiza wyników badań}

Przeprowadzone badania wykazały, iż sposób przygotowania ciepłej wody użytkowej posiada istotny wpływ zarówno na efektywność finansową inwesty- 
cji, jak i na komfort użytkowania systemu oraz wpływ jego eksploatacji na środowisko.

Zastosowanie urządzenia DWHR umożliwi odzysk około $7 \mathrm{~kW}$ energii odpadowej niesionej przez odprowadzane z prysznica ścieki szare, czego następstwem będzie wzrost temperatury przepływającej przez wymiennik ciepła wody o ponad $22^{\circ} \mathrm{C}$. Wykorzystanie takiego rozwiązania systemu przygotowania ciepłej wody użytkowej pozwoli także zredukować zużycie gazu ziemnego wysokometanowego $\mathrm{w}$ analizowanym budynku o ponad $180 \mathrm{~m}^{3}$ rocznie, co stanowi prawie $25 \%$ obecnego zużycia paliwa na potrzeby podgrzewania wody.

Eksploatacja opisanego zestawu solarnego umożliwi natomiast pokrycie zapotrzebowania na energię wykorzystywaną w celu przygotowania ciepłej wody użytkowej w ponad 70\% w skali roku. Wykonana analiza wykazała, iż najmniejszy udział energii promieniowania słonecznego w całkowitym zużyciu energii na ten cel, nieznacznie przekraczający 30\%, odnotowany zostanie w okresie od listopada do stycznia. W miesiącach o najwyższym natężeniu promieniowania słonecznego realne będzie natomiast pokrycie całego zapotrzebowania energią odnawialną.

Wyniki zrealizowanych badań efektywności finansowej rozpatrywanych wariantów inwestycyjnych wskazują wyraźnie, iż przy założonych parametrach użytkowania instalacji bardziej korzystny jest wariant 1 , którego założeniem jest odzysk ciepła odpadowego niesionego przez ścieki szare. W przypadku gdy okres eksploatacji systemu wynosi $n=15$ lat, wartość zaktualizowana netto takiego przedsięwzięcia osiąga wartość $N P V_{1}=139,19$ zł i należy go uznać za opłacalne pod względem finansowym. Potencjalne oszczędności jednak tylko nieznacznie przewyższają $\mathrm{w}$ tym przypadku konieczne do poniesienia nakłady inwestycyjne, co powoduje, iż wariant ten jest bardzo podatny na zmiany wysokości cen paliwa gazowego.

Z kolei w wariancie 2 wysokość analizowanego wskaźnika jest ujemna i wynosi $N P V_{2}=-4265,85 \mathrm{zl}$, co wskazuje na nieopłacalność takiej alternatywy decyzyjnej. Posiada ona jednak dodatkowy atut w postaci możliwości uzyskania dofinansowania [22], które znacznie ograniczyłoby konieczne do poniesienia nakłady inwestycyjne.

Analiza wpływu użytkowania poszczególnych rozwiązań systemu przygotowania ciepłej wody użytkowej na środowisko wskazuje natomiast na sporą przewagę wariantu 2, co przedstawiono w tabeli 2. Negatywne oddziaływanie spalania paliw kopalnych na środowisko związane jest bowiem nie tylko z nadmierną eksploatacją ich zasobów naturalnych, ale także emisją do atmosfery znacznej ilości zanieczyszczeń, w których dominującą rolę odgrywa dwutlenek węgla. Ograniczenie zużycia gazu ziemnego o ponad $500 \mathrm{~m}^{3}$ rocznie, będące efektem zainstalowania kolektorów słonecznych na dachu rozpatrywanego obiektu, pozwoliłoby na zmniejszenie emisji tego gazu o około $1080 \mathrm{~kg} \mathrm{w}$ skali roku, co w całym cyklu życia systemu daje wartości przekraczające $16000 \mathrm{~kg} \mathrm{CO}$. W przypadku zastosowania systemu odzysku ciepła ze ścieków 
szarych odprowadzanych z prysznica (wariant 1) redukcja emisji zanieczyszczeń jest niemal trzykrotnie niższa. Należy jednak pamiętać, że działanie systemu solarnego uzależnione jest od dostępności energii elektrycznej, której zużycia nie uwzględniono w niniejszej analizie emisji zanieczyszczeń. Wykorzystanie energii elektrycznej nie przyczynia się co prawda do powstawania małych źródeł emisji, jednakże w wielu przypadkach do jej produkcji zużywane są paliwa kopalne.

Tabela 2. Emisja zanieczyszczeń związana z eksploatacją systemu przygotowania ciepłej wody użytkowej w analizowanym budynku w okresie $n=15$ lat

Table 2. Emissions associated with the operation of a hot water system in the analyzed building during the lifetime of the system $(n=15$ years)

\begin{tabular}{|c|c|c|c|c|}
\hline \multirow{2}{*}{$\begin{array}{c}\text { Rodzaj } \\
\text { zanieczyszczenia }\end{array}$} & \multirow{2}{*}{ Jednostka } & \multicolumn{3}{|c|}{$\begin{array}{c}\text { Emisja zanieczyszczeń w okresie } \\
\text { eksploatacji } \boldsymbol{n}=\mathbf{1 5} \text { lat }\end{array}$} \\
\cline { 3 - 5 } & & wariant 0 & wariant 1 & wariant 2 \\
\hline $\mathrm{CO}_{2}$ & $\mathrm{~kg}$ & 22311,45 & 16819,95 & 6112,65 \\
\hline $\mathrm{NO}_{\mathrm{x}} / \mathrm{NO}_{2}$ & $\mathrm{~kg}$ & 16,96 & 12,78 & 4,65 \\
\hline $\mathrm{SO}_{\mathrm{x}} / \mathrm{SO}_{2}$ & $\mathrm{~g}$ & 892,46 & 672,80 & 244,51 \\
\hline $\mathrm{CO}$ & $\mathrm{g}$ & 3346,72 & 2522,99 & 916,90 \\
\hline Pył zawieszony całkowity & $\mathrm{g}$ & 0,56 & 0,42 & 0,15 \\
\hline
\end{tabular}

Analiza pozostałych elementów modelu decyzyjnego dotyczącego wyboru sposobu podgrzewania wody $\mathrm{w}$ budynku przeprowadzona została w oparciu o opinie ekspertów. Przyjętym kryteriom decyzyjnym przypisano współczynniki wagowe, natomiast oceny rozpatrywanych opcji decyzyjnych pod kątem spełnienia tych kryteriów dokonano poprzez przyporządkowanie im odpowiedniej liczby punktów. Zgodnie z zaleceniami [18] badane warianty inwestycyjne oceniono w skali $0-10$.

W tabeli 3 zestawiono wyniki badań uzyskane dla wariantu 1, zakładającego wykorzystanie urządzenia DWHR. Z kolei tabela 4 przedstawia końcowe rezultaty analizy wieloatrybutowej, którą przeprowadzono w celu wyboru optymalnego rozwiązania systemu podgrzewania wody w przedmiotowym budynku mieszkalnym. $\mathrm{Z}$ uwagi na to, iż jedynym paliwem kopalnym uwzględnionym w analizie jest gaz ziemny, podkryteria $K_{42}-K_{45}$ zastąpiono jednym podkryterium $K_{42}$ : Niska emisja zanieczyszczeń.

Łączne oceny rozpatrywanych wariantów modernizacji instalacji przygotowania ciepłej wody użytkowej w budynku wskazują, że przy przyjętych wartościach współczynników wagowych najbardziej korzystny jest wariant 2 , który okazał się nieopłacalny pod względem finansowym. Tak wysoka pozycja tej opcji decyzyjnej w uzyskanym rankingu końcowym związana jest głównie 
z pozytywnym wpływem eksploatacji instalacji solarnej na otaczające nas środowisko. W przypadku analizowanego obiektu emisja zanieczyszczeń może zostać ograniczona o ponad 70\%. Powoduje to, iż pomimo konieczności poniesienia wysokich nakładów inwestycyjnych na realizację takiej instalacji oraz wymogu regularnego wykonywania jej przeglądów technicznych, wariant 2 stanowi doskonałą alternatywę dla tradycyjnych rozwiązań.

Tabela 3. Wyniki analizy wieloatrybutowej wariantu 1

Table 3. The results of the multi-attribute analysis of variant 1

\begin{tabular}{|c|c|c|c|c|c|}
\hline $\begin{array}{l}\text { Kryteria } \\
\text { decyzyjne }\end{array}$ & Wagi & $\begin{array}{c}\text { Podkryteria } \\
\text { decyzyjne }\end{array}$ & Wagi & Oceny & $\begin{array}{c}\text { Iloczyny } \\
\text { wag i ocen }\end{array}$ \\
\hline \multirow{2}{*}{$K_{1}$} & \multirow{2}{*}{0,15} & $\mathrm{~K}_{11}$ & 0,80 & 3 & 0,360 \\
\hline & & $\mathrm{K}_{12}$ & 0,20 & 0 & 0,000 \\
\hline \multirow{5}{*}{$K_{2}$} & \multirow{5}{*}{0,25} & $\mathrm{~K}_{21}$ & 0,25 & 9 & 0,563 \\
\hline & & $\mathrm{K}_{22}$ & 0,20 & 8 & 0,400 \\
\hline & & $\mathrm{K}_{23}$ & 0,25 & 9 & 0,563 \\
\hline & & $\mathrm{K}_{24}$ & 0,20 & 6 & 0,300 \\
\hline & & $\mathrm{K}_{25}$ & 0,10 & 8 & 0,200 \\
\hline \multirow{2}{*}{$K_{3}$} & \multirow{2}{*}{0,10} & $\mathrm{~K}_{31}$ & 0,70 & 10 & 0,700 \\
\hline & & $\mathrm{K}_{32}$ & 0,30 & 2 & 0,060 \\
\hline \multirow{2}{*}{$K_{4}$} & \multirow{2}{*}{0,30} & $\mathrm{~K}_{41}$ & 0,50 & 4 & 0,600 \\
\hline & & $\mathrm{K}_{42}$ & 0,50 & 4 & 0,600 \\
\hline \multirow{5}{*}{$K_{5}$} & \multirow{5}{*}{0,20} & $\mathrm{~K}_{51}$ & 0,15 & 8 & 0,240 \\
\hline & & $\mathrm{K}_{52}$ & 0,20 & 0 & 0,000 \\
\hline & & $\mathrm{K}_{53}$ & 0,10 & 5 & 0,100 \\
\hline & & $\mathrm{K}_{54}$ & 0,30 & 6 & 0,360 \\
\hline & & $\mathrm{K}_{55}$ & 0,25 & 8 & 0,400 \\
\hline & & & & & $\Sigma 5,445$ \\
\hline
\end{tabular}

Tabela 4. Zestawienie wyników analizy

Table 4 . The summary of the results

\begin{tabular}{|c|c|c|}
\hline Pozycja w rankingu & Wariant & Ocena lączna \\
\hline 1 & 2 & 5,493 \\
\hline 2 & 1 & 5,445 \\
\hline 3 & 0 & 4,748 \\
\hline
\end{tabular}


Drugą pozycję w rankingu końcowym zajmuje wariant 1 . Należy jednak zwrócić uwagę na fakt, iż uzyskana przez tę opcję ocena jest niższa od oceny wariantu 2 o niespełna $1 \%$, co sprawia, że również to rozwiązanie może z powodzeniem zastąpić istniejący system przygotowania ciepłej wody. Jego wpływ na poprawę stanu środowiska naturalnego jest co prawda zdecydowanie mniejszy niż systemu wykorzystującego energię promieniowania słonecznego, jednakże zastosowanie wymiennika ciepła DWHR pozwala osiągnąć oszczędności finansowe, które przewyższają swą wysokością nakłady inwestycyjne. Dodatkowo eksploatacja instalacji odzysku ciepła ze ścieków szarych odprowadzanych z prysznica nie wymaga wykonywania częstych zabiegów konserwacyjnych, a producenci urządzeń tego typu deklarują, że mogą one sprawnie funkcjonować nawet przez kilkadziesiąt lat, dzięki czemu rzeczywiste zyski z realizacji takiego systemu mogą znacznie przekroczyć te wyznaczone w analizie. Warto również zwrócić uwagę na fakt, iż działanie systemu DWHR jest praktycznie niezależne od warunków pogodowych. $\mathrm{Z}$ tego względu system ten może z powodzeniem być stosowany także w tych częściach naszego kraju, które charakteryzują się mniejszym nasłonecznieniem.

Przeprowadzona analiza wieloatrybutowa wykazała ponadto, że w świetle rozpatrywanych kryteriów najgorszym rozwiązaniem jest pozostanie przy obecnym sposobie podgrzewania wody. Użytkowanie systemu, którego funkcjonowanie oparte jest jedynie na surowcach nieodnawialnych, prowadzi bowiem do degradacji środowiska przyrodniczego oraz uzależnia odbiorcę energii od dostępności paliw kopalnych.

\section{Podsumowanie}

Przeprowadzone badania zasadności zastosowania różnych rozwiązań systemu przygotowania ciepłej wody użytkowej w jednorodzinnym budynku mieszkalnym wykazały, że w przypadku uwzględnienia różnych czynników decyzyjnych, w tym środowiskowych i społecznych, racjonalnym okazuje się wykorzystanie alternatywnych źródeł energii, do których zaliczane są nie tylko źródła odnawialne, ale także odpadowe. W analizowanym przypadku zarówno instalacja kolektorów słonecznych, jak i urządzenia DWHR, jest korzystniejszym rozwiązaniem niż pozostanie tylko przy tradycyjnym źródle energii, to jest kotle gazowym.

Wyniki wykonanej analizy dowodzą także, iż decyzja o wyborze konkretnego wariantu inwestycyjnego nie może być podejmowana ani intuicyjnie ani w oparciu o tylko jedno kryterium, jakim zazwyczaj jest kryterium finansowe. W rozważanym przypadku opłacalność wariantu 1 jest bowiem znikoma, natomiast wariant 2 jest w świetle kryterium ekonomicznego całkowicie nierentowny. Obie opcje modernizacji istniejącego systemu podgrzewania wody posiadają jednak szereg walorów, których występowanie ogranicza znaczenie ich negatywnych stron. 


\section{Literatura}

[1] Belton V., Stewart T.J.: Multiple Criteria Decision Analysis. An Integrated Approach, Springer Science + Business Media, B.V., Dordrecht 2002.

[2] Bertrand A., Mastrucci A., Schüler N., Aggoune R., Maréchal F.: Characterisation of domestic hot water end-uses for integrated urban thermal energy assessment and optimisation, Applied Energy, http://dx.doi.org/10.1016/j.apenergy.2016.02.107, 2016 (in press).

[3] Brealey R.A., Myers S.C., Allen F.: Principles of Corporate Finance, McGraw-Hill/Irwin, New York 2011.

[4] Catalina T., Virgone J., Blanco E.: Multi-source energy systems analysis using a multi-criteria decision aid methodology, Renewable Energy, vol. 36, 2011, pp. 2245-2252.

[5] Chen J.F., Dai Y.J., Wang R.Z.: Experimental and theoretical study on a solar assisted $\mathrm{CO}_{2}$ heat pump for space heating, Renewable Energy, vol. 89, 2016, pp. 295-304.

[6] Chudzicki J., Sosnowski S.: Instalacje wodociągowe: projektowanie, wykonanie, eksploatacja, Wydawnictwo „Seidel-Przywecki”, Warszawa 2009.

[7] Czarniecki D., Pisarev V., Dziopak J., Słyś D.: Analiza techniczna i finansowa instalacji do odzysku ciepła ze ścieków w budynkach wielorodzinnych [w:] Interdyscyplinarne zagadnienia w inżynierii i ochronie środowiska. Tom 4, (pod red.) Traczewska T.M., Kaźmierczak B., Oficyna Wydawnicza Politechniki Wrocławskiej, Wrocław 2014, s. 132-148.

[8] Czarniecki D., Słyś D.: Analiza techniczna i finansowa odzysku ciepła odpadowego ze ścieków w miasteczku akademickim Politechniki Rzeszowskiej, Technologia wody, nr 4, 2015, s. 73-81.

[9] Diego-Ayala U., Carrillo-Baeza J.G.: Study of the Thermal Behaviour of Water for Residential Use in Tanks of Concrete and Polyethylene in Humid Subtropical Climate, Ingeniería Investigación y Tecnología, vol. 16, 2015, pp. 573-583.

[10] Dz.U. 2015 poz. 376: Rozporządzenie Ministra Infrastruktury i Rozwoju z dnia 27 lutego 2015 r. w sprawie metodologii wyznaczania charakterystyki energetycznej budynku lub części budynku oraz świadectw charakterystyki energetycznej.

[11] Evins R., Orehounig K., Dorer V.: Variability between domestic buildings: the impact on energy use, Journal of Building Performance Simulation, vol. 9, 2016, pp. 162-175.

[12] Figueira J., Greco S., Ehrgott M. (red.): Multiple Criteria Decision Analysis: State of the Art Surveys, Springer Science + Business Media, Inc., Boston 2005.

[13] Ghelli A., Hagras H., Aldabbagh G.: A Fuzzy Logic-Based Retrofit System for Enabling Smart Energy-Efficient Electric Cookers, IEEE Transactions on Fuzzy Systems, vol. 23, 2015, pp. 1984-1997.

[14] Główny Urząd Statystyczny: Efektywność wykorzystania energii w latach 2003-2013. Informacje i opracowania statystyczne, Warszawa 2015.

[15] Kordana S., Słyś D., Dziopak J.: Rationalization of water and energy consumption in shower systems of single-family dwelling houses, Journal of Cleaner Production, vol. 82, 2014, pp. 58-69. 
[16] KOBiZE: Wskaźniki emisji zanieczyszczeń ze spalania paliw: kotły o nominalnej mocy cieplnej do 5 MW, IOŚ-PIB, Warszawa 2015.

[17] Kušnír M., Vranay M., Košičanová D., Vranayová Z., Kapalo P., Gavlík M.: Utilizing solar energy in order to reduce energy loads of building, Chemical Engineering Transactions, vol. 39, 2014, pp. 1483-1488.

[18] Nowak M. (red.): Wspomaganie decyzji w planowaniu projektów, Difin, Warszawa 2014.

[19] O’Connor D., Calautit J.K.S., Hughes B.: A review of heat recovery technology for passive ventilation applications, Renewable \& Sustainable Energy Reviews, vol. 54, 2016, pp. 1481-1493.

[20] Obszary rozliczenia ciepła spalania, http://www.psgaz.pl/obszary-rozliczeniaciepla-spalania/ \{dostęp: 21.03.2016 r. $\}$.

[21] Pochwat K., Słyś D., Dziopak J.: Analiza opadów na potrzeby wymiarowania sieci i zbiorników retencyjnych w kanalizacji, Gaz, Woda i Technika Sanitarna, nr 7, 2013, s. 269-272.

[22] Prosument-dofinansowanie mikroinstalacji OZE, https://www.nfosigw.gov.pl/ oferta-finansowania/srodki-krajowe/programy-priorytetowe/prosument-dofinans owanie-mikroinstalacji-oze/ \{dostęp: 24.03.2016 r. \}.

[23] Rocha H., Peretta I.S., Lima G.F.M., Marques L.G., Yamanaka K.: Exterior lighting computer-automated design based on multi-criteria parallel evolutionary algorithm: optimized designs for illumination quality and energy efficiency, Expert Systems with Applications, vol. 45, 2016, pp. 208-222.

[24] Słyś D., Kordana S.: Financial analysis of the implementation of a Drain Water Heat Recovery unit in residential housing, Energy and Buildings, vol. 71, 2014, pp. 1-11.

[25] Słyś D., Kordana S.: Odzysk ciepła odpadowego w instalacjach i systemach kanalizacyjnych, Wydawnictwo i Handel Książkami „KaBe”, Krosno 2013.

[26] Starzec M., Dziopak J., Alexeev M.I.: Effect of the sewer basin increasing to necessary useful capacity of multichamber impounding reservoir, Water and Ecology, vol. 1, 2015, pp. 41-50.

[27] Stec A., Kordana S.: Analysis of profitability of rainwater harvesting, gray water recycling and drain water heat recovery systems, Resources, Conservation and Recycling, vol. 105, 2015, pp. 84-94.

[28] Svintsov A.P., Kharun M.I., Mukarzel S.A.: Valve head for water fittings with high regulatory capacity, Magazine of Civil Engineering, no 6, 2015, pp. 8-18.

[29] Typowe lata meteorologiczne i statystyczne dane klimatyczne dla obszaru Polski do obliczeń energetycznych budynków, https://danepubliczne.gov.pl/ \{dostęp: 16.03.2016 r. \}.

[30] Urmee T., Thoo S., Killick W.: Energy efficiency status of the community housing in Australia, Renewable \& Sustainable Energy Reviews, vol. 16, 2012, pp. 1916-1925.

[31] Wallin J., Claesson J.: Investigating the efficiency of a vertical inline drain water heat recovery heat exchanger in a system boosted with a heat pump, Energy and Buildings, vol. 80, 2014, pp. 7-16. 
[32] Wyrębski P., Fryze A.: Odzyskiwanie ciepła ze ścieków, Ciepłownictwo, Ogrzewnictwo, Wentylacja, nr 10, 2014, s. 385-386.

[33] Yu Z., Fung B.C.M., Haghighat F., Yoshino H., Morofsky E.: A systematic procedure to study the influence of occupant behavior on building energy consumption, Energy and Buildings, vol. 43, 2011, pp. 1409-1417.

[34] Zeleňáková M., Gaňová L., Purcz P., Satrapa L.: Methodology of flood risk assessment from flash floods based on hazard and vulnerability of the river basin, Natural Hazards, vol. 79, 2015, pp. 2055-2071.

[35] Zhang P., Ye J., Zeng G.: Thermal Effects, Water Environment Research, vol. 87, 2015, pp. 1901-1913.

\section{DECISION SUPPORT FOR SELECTING THE MOST FAVORABLE VARIANT OF HOT WATER SYSTEM}

\section{S u m m a r y}

Currently, the tendency to reduce the energy consumption of buildings is observed in Poland. Nevertheless, the possibilities to reduce the energy demand for space heating are the main subject of interest, while the ways to minimize energy use for hot water heating are underestimated. Meanwhile, domestic hot water preparation is the second largest item in the balance of energy consumption of buildings and this is the incentive to save energy used to heat water. The need to incur high investment costs for sustainable hot water systems is, however, a problem. In response to the above issue, the criteria which determine the optimal choice of hot water system have been defined. The analysis for the typical single-family dwelling house has also been carried out. The scoring method, which is one of the most commonly used multi-attribute decision-making methods, has been chosen as the tool for assessing the considered modernization variants of the existing water heating system. Studies have shown that taking into account a number of criteria, such as economic, environmental, operating, social and technical ones, allows the indication of the advantages of such investments. The obtained results have also confirmed that these advantages of the analyzed systems significantly exceed the drawbacks.

Keywords: decision criteria, drain water heat recovery, multi-attribute decision making methods, solar energy harnessing

DOI: $10.7862 / \mathrm{rb} .2016 .162$

Przestano do redakcji: $01.05 .2016 r$.

Przyjęto do druku: 28.06.2016 r. 